\title{
Habitat Characteristics of Bracken- Covered Areas Intended for Afforestation in Ličko Sredogorje
}

\section{Zvonko Seletković ${ }^{1}$, Damir Ugarković ${ }^{2 \Xi}$, Ivan Seletković ${ }^{1}$, Nenad Potočić ${ }^{1}$}

\author{
${ }^{1}$ Croatian Forest Research Institut, Department of Ecology and Silviculture, Cvjetno naselje 41, \\ 10450 Jastrebarsko, Croatia \\ 2 Faculty of Forestry, Department of Forest Ecology and Silviculture, Svetošimunska 25, \\ 10000 Zagreb, Croatia
}

$\varangle$ Corresponding author: e-mail: damir.ugarkovic@gs.htnet.hr

Citation:

SELETKOVIĆ Z, UGARKOVIĆ D, SELETKOVIĆ I, POTOČIĆ N 2013 Habitat Characteristics of Bracken-Covered Areas Intended for Afforestation in Ličko Sredogorje. South-East Eur For 4 (2): 105-114

\begin{abstract}
Background and Purpose: Forest cultures in continental part of Croatia are mainly based on bracken-covered areas and moors on deserted agriculture soils and pastures. Successful afforestation i.e. establishment of forest cultures depends among other things on the understanding of habitats and ecology of forest trees. The choice of best species of forest trees for afforestation needs to be based on the research in soil and climate characteristics of target habitats. The aims of this research were to show mesoclimatic characteristics of Ličko sredogorje and microclimatic and pedological characteristics of Ličko polje. Also, based on habitat characteristics and ecology of forest trees, the aim was to determine species of forest trees suitable for afforestation of bracken-covered areas.
\end{abstract}

Materials and Methods: Climate, microclimate, pedological and plant nutrition researches were done at the area of Lika highlands. Climate analysis was done according to air temperatures, amount of precipitation, relative air humidity and other climate elements and appearances. Composite soil samples were taken from the depth of $0-30 \mathrm{~cm}$ in order to determine plant nutrition potential. Samples were prepared for further analysis in the laboratory.

Results: The highest average annual air temperature of $9.6^{\circ} \mathrm{C}$ was found at weather station Gračac and the lowest at Korenica station $\left(8.1^{\circ} \mathrm{C}\right)$. Average amount of precipitation for this region was around $1500 \mathrm{~mm}$. Monthly rain factors were ranging from arid to perhumid. Considering thermal character of the climate, the area has moderately warm climate. Average volumetric soil humidity is $14.2 \%$. Soil has strong acid reaction, is very humus, good to richly supplied with total nitrogen, content of physiologically active phosphorus and potassium is low, and C/N ration normal.

Conclusions: According to habitat characteristics in the area of Ličko sredogorje and ecological demands of forest tree species, forest cultures of Common birch (Betula pendula Roth.), Common spruce (Picea abies Karst.), Eastern white pine (Pinus strubus L.), Black pine (Pinus nigra subsp. austriaca Asch i Gr.), Common pine (Pinus sylvestris L.) and European trembling aspen (Populus tremula L.) can be established.

Keywords: habitat, climate, soil, afforestation, ecology of forest trees 


\section{INTRODUCTION}

Planned and organized works on the establishment of cultures of conifers in the continental part of Croatia started around 1960. The first afforestations were mostly done by sowing the seeds, particularly in the karst areas, and later it was done with seedlings produced in forest nurseries. Pedological, ecological and plant nutrition researches have been done with a goal to choose the most suitable species, that is, the provenance for sowing on certain habitats and such researches have until 1992 encompassed an area of over 25000 ha [1].

Forest cultures of conifers are being established with different goals. They can have a determined purpose, ex. production of trees for cellulose and thinner technical timber, for soil protection against erosion, for enriching the landscape and for increasing forest functions of general benefit, for the production of Christmas trees, and lately for the production of biomass for energy purposes.

Others are established as pre-cultures with the goal of establishing conditions for the return of indigenous forest trees, and consequently, of forming a natural forest ecosystem.

According to Čavlović [2] Croatia has 33070 ha of evergreen and 10080 ha of deciduous plantations. Forest conifer cultures in the continental part of Croatia are mostly established on bracken-covered areas and moors on deserted agriculture soils and pastures.

It is estimated that Croatia has around 300000 ha of such area. Conifer cultures of the continental part of Croatia are divided as follows Common spruce $55 \%$, Common pine $20 \%$, Eastern white pine $5 \%$, European larch $4 \%$ and other conifer types $1 \%$.

The first conifer cultures in Lika have been established between 1856 and 1896 and they have included Scots pine and Austrian black pine on the territory "Vujnović brdo" on the surface of 120 ha. The Municipality of Otočac has in 1896 afforested Laudonov gaj on quicksand soil with Common pine and Black pine. Between 1964 and 1968 on the territory of Medak and Žitnik, 114.88 ha of plantations and 1102.26 ha of intensive fast growing conifers have been established which included Common pine (483 ha), Eastern white pine (142 ha), European larch (256 ha), Common spruce (314 ha) and Black pine (20 ha).

According to Komlenović [3] before establishing forest cultures every surface requires a detailed research and special attention needs to be dedicated to soil reactions.

The goal of this research is to show the mesoclimatic characteristics of Ličko sredogorje as well as micro-climatic and pedological characteristics of Ličo polje and based on the habitat's characteristics and the ecology of forest trees, to determine types of forest trees for afforestation of forest land covered with bracken.

\section{MATERIALS AND METHODS}

Climate analysis on the territory of Ličko sredogorje was done according to air temperatures, amount of precipitation, relative air humidity and some other climate elements and appearances received from the weather stations in Gospić, Gračac and Korenica for the period 1981 - 2010.

The site Medačke staze was selected for additional micro-climate and plant nutrition research due to the need for afforestation of that area. Micro climate research was done in 2010 and 2011 on the territory of Ličko polje, management unit "Medačke staze", subcompartments 39a, 51a and 63, of the Forest office Gospić. Measurements were executed in a time interval of one hour using a micro-climate station "Spectrum". The measurements included measuring air temperature $\left({ }^{\circ} \mathrm{C}\right)$ at the height of $1 \mathrm{~m}$ and soil temperature $\left({ }^{\circ} \mathrm{C}\right)$ at the depth of $10 \mathrm{~cm}$, as well as volumetric soil humidity VWC (\%) up to a depth of $20 \mathrm{~cm}$. 
Composite soil samples were taken from the same sites from the depth of $1-30 \mathrm{Cm}$ for the reason of determining plant nutrition soil potential. The samples were consequently taken to the laboratory where they were airdried, chopped up, sieved through a mesh with $2 \mathrm{~mm}$ wide holes and in such a way prepared for further analysis [4]. The samples were then analysed for the $\mathrm{pH}$ in water and $1 \mathrm{MKCl}[5]$, the total content of nitrogen was determined in the elementary analyser Leco CNS 2000 [6], the humus content according to Tjurin [4], and the physiological active phosphor and potassium according to Egnér, Riehm and Domingo [7]. Soil analysis was done in the Laboratory for physical-chemical testing of the Croatian Forest Research Institute.

The data was processed in the programmes KlimaSoft 2.0 [8], SpecWare 8.0 [9] and Statistica 7.1. [10].

\section{RESULTS}

\section{Air temperature}

Looking at the average annual air temperatures in Table 1 for the listed weather stations, we notice a temperature difference between stations. Maximal average annual air temperature of $9.6{ }^{\circ} \mathrm{C}$ was measured in the Gračac station, and the minimal of 8.1 ${ }^{\circ} \mathrm{C}$ in Korenica. According to many authors, average air temperatures for the vegetative period (April-September) has a much greater significance for the development of vegetation than average annual air temperatures which in certain years depends significantly on the air temperature during the winter period. Average temperatures for the vegetative period were: Korenica $14.1^{\circ} \mathrm{C}$, Gospić $15.2^{\circ} \mathrm{C}$ and Gračac $15.6^{\circ} \mathrm{C}$. Once again, Gračac stands out with the hottest vegetative period.

Absolute maximal and minimal air temperatures show realistic and total temperature differences in a specific area. They can frequently be a limiting factor for the incoming, development and survival of a species [11]. Good indentation, and particularly relief factors such as height above sea level and inclination, very often influence on significant deviations even in the air temperature extremes. The lowest air temperature on the weather station Gračac was $34.6{ }^{\circ} \mathrm{C}$. On the Gospić and Korenica territory, the minimal air temperatures were $27.3{ }^{\circ} \mathrm{C}$, respectively, $-27.6{ }^{\circ} \mathrm{C}$. The absolute maximal air temperatures were also very high for this climate type. The weather station in Gračac registered the absolute maximal air temperature of $38.3^{\circ} \mathrm{C}$. On the Gospić and Korenica territory, the maximal air temperatures were $37.0^{\circ} \mathrm{C}$, res-pectively, 36.8 ${ }^{\circ} \mathrm{C}$.

\section{Precipitation}

Average amount of precipitation for this area was around $1500 \mathrm{~mm}$. Table 1 shows the monthly and annual amount of precipitation for the observed weather stations. The researched area has a maritime precipitation regime. The biggest part of precipitation occurs during the colder part of the year, except on the weather station in Korenica. Maximal monthly amount of precipitation occurs in late autumn or in the beginning of winter, while July is a month with the minimal amount of precipitation.

The percentage of precipitation in the vegetative period is the highest on the territory of Korenica and it was $50.3 \%$. The percentage of precipitation for the weather station in Gračac is least favourable and it was $36.4 \%$, and it is followed by Gospić with 43.1 $\%$. The most favourable precipitation regime is in Korenica where the precipitation is equally distributed during the whole year. The highest number of rainy days was measured on the Gospić area (143 days), then Gračac (128 days) and the lowest on the Korenica territory (105 days). During the vegetative period, a surplus of water in the soil was noticed on the Ličko sredogorje territory. The values of potential evapotranspiration were less than the amount of rainfall (Figure 1).

Monthly rain factors shifted from arid to perhumid. Considering the heat character of 
SELETKOVIĆ Z, UGARKOVIĆ D, SELETKOVIĆ I, POTOČIĆ N

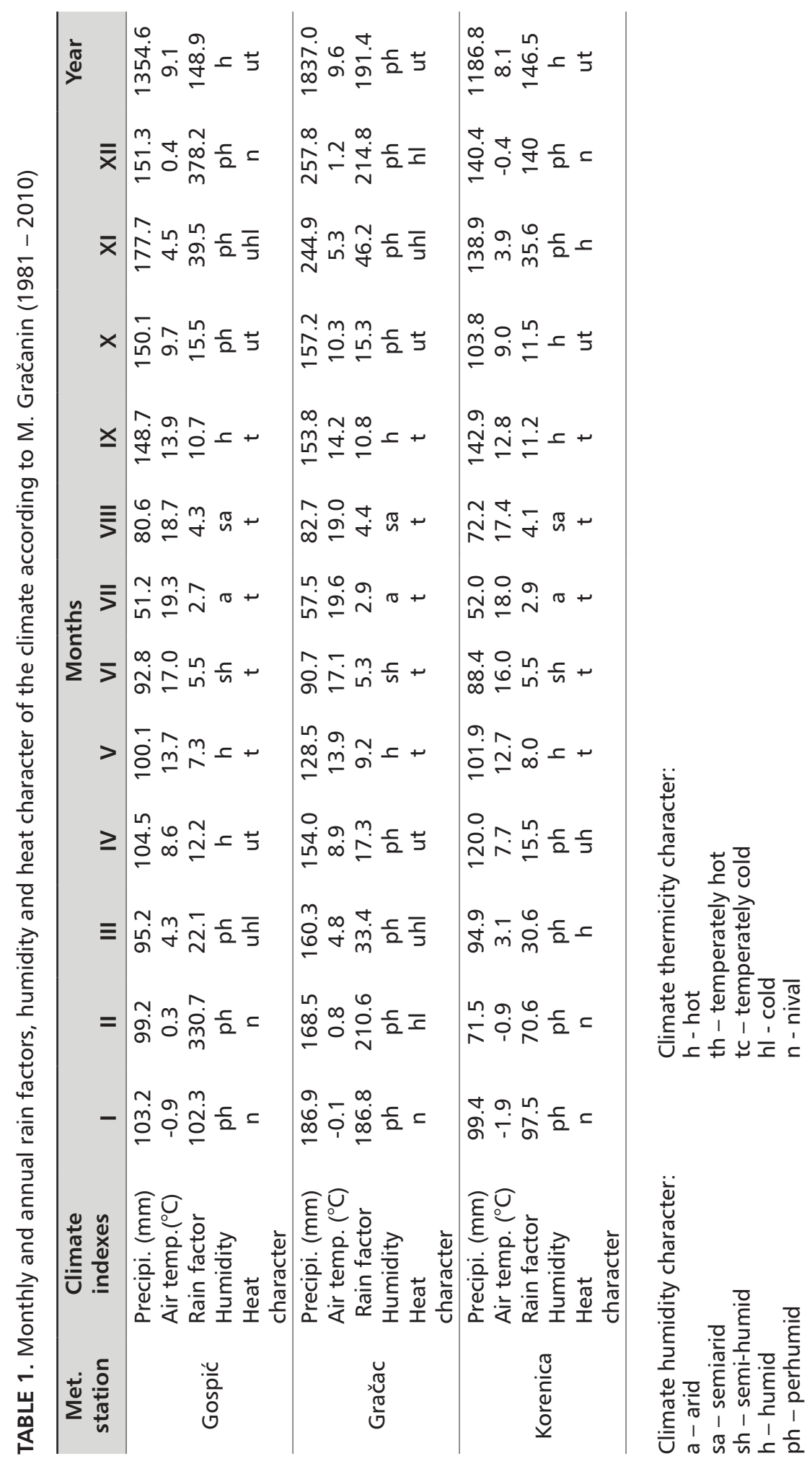

108 SEEFOR 4 (2): 105-114

(C) CFRI http://www.seefor.eu 
the climate, the weather stations are located on the territory of moderately warm climate. Hot months were not registered on any of the weather stations. Considering the heat character of the climate, during the year we have registered 5 hot months (h), from one to three months with snowfall (s), one to two temperately cold and cold months (tc and c), one to two temperately hot months (th). Temperately cold months (tc) occurred one on the territory of Gospić and Korenica, and two such months occurred on the Gračac territory (Table 1).

\section{Air humidity}

In the period from 1981 to 2010, on the three observed weather stations in Ličko sredogorje, maximal relative air humidity values were measured in December (rarely in November), except from the weather station Korenica where its peak was measured in April. The minimal values were measured in July.

In the observed period, the listed weather stations did not measure extremely humid or extremely dry air because the average annual value of air humidity was not higher than $90 \%$ or lower than $40 \%$ except for the weather station in Korenica, where February, March, April, May, November and December were extremely humid. The average annual air humidity level was temperate (Gospić and Gračac $78 \%$ ) up to very high (Korenica $89 \%$ ).

\section{Climate indexes}

Table 2 shows some of the climate indexes which determine the climate of the researched territory. The Ličko sredogorje territory, considering the value of the Lang annual rain factor, belongs to perhumid and humid

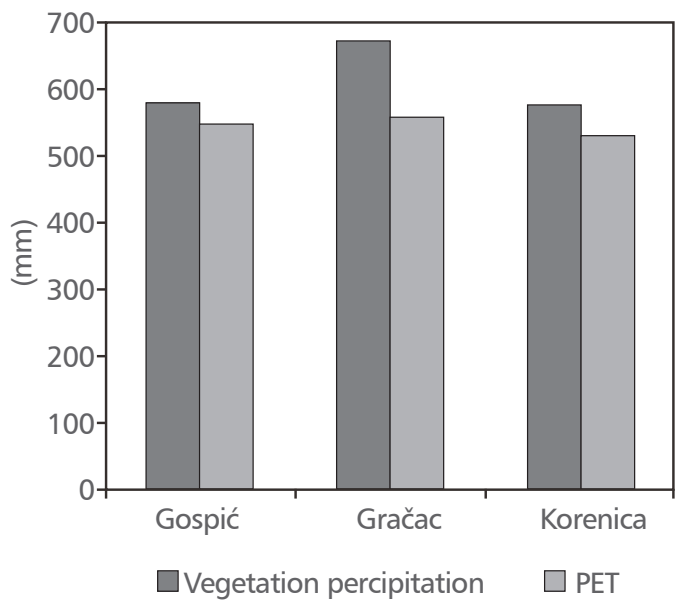

FIGURE 1. Relation between precipitation amount and potential evapotranspiration (PET)

climate. Considering the Martonne's index of aridity, which varied from 67.7 (Korenica) to 94.1 (Gračac), these are considered to be humid areas.

Considering the value of the index of continentality, the study area has continental climate. According to the value of the thermal coefficient (from 5.4 for Gospić to 7.1 for Gračac), weather stations are located on the area characterized by temperate continental climate (Table 2).

\section{Climate appearance}

On the territory of Ličko sredogorje frost appears frequently. Fog is also frequent but also very interesting and important from the ecological point of view because it increases the total value of air humidity and creates additional amounts of precipitation.

According to the number of days with snow $(\geq 1 \mathrm{~cm})$, the first places holds the weather

TABLE 2. Climate factors and indexes of weather stations Gospić, Gračac and Korenica (1981 - 2010)

\begin{tabular}{cccccc}
\hline Met. station & $\begin{array}{c}\text { Lang's rain } \\
\text { factor }\end{array}$ & $\begin{array}{c}\text { Martonn's } \\
\text { aridity index }\end{array}$ & $\begin{array}{c}\text { Emberger's } \\
\text { Pluviotermic } \\
\text { quotient }\end{array}$ & $\begin{array}{c}\text { Konrad's } \\
\text { index of } \\
\text { continentality }\end{array}$ & $\begin{array}{c}\text { Krener's } \\
\text { thermic } \\
\text { quotient }\end{array}$ \\
\hline Gospić & 148.9 & 70.8 & 205.1 & 51.3 & 5.4 \\
Gračac & 191.4 & 94.1 & 253.8 & 49.7 & 7.1 \\
Korenica & 146.5 & 67.7 & 205.6 & 61.4 & 6.5 \\
\hline
\end{tabular}


TABLE 3. Descriptive statistics of microclimate in Ličko polje in 2011

\begin{tabular}{cccccc}
\hline Microclimatics elements & N & Mean & Min. & Max. & Std. Dev. \\
\hline Air temperature $\left({ }^{\circ} \mathrm{C}\right)$ & 8025 & 10.5 & -10.3 & 37.3 & 7.38 \\
Soil temperature $\left({ }^{\circ} \mathrm{C}\right)$ & 8025 & 11.3 & 2.7 & 22.1 & 5.91 \\
Volumetric water content $(\%)$ & 8025 & 14.2 & 0.8 & 26.2 & 3.67 \\
\hline
\end{tabular}

station Korenica with 165 days, it is followed by Gospić with 117 days and finally Gračac with 72 days. According to the documented amount of snowfall, Gračac stands out with $135 \mathrm{~cm}$, it is followed by Korenica with $128 \mathrm{~cm}$ and Gospić with $117 \mathrm{~cm}$ of snow on the ground.

\section{Microclimate}

Average annual air temperature on the Ličkog polje area was $10.5^{\circ} \mathrm{C}$, and the soil temperature was $11.3^{\circ} \mathrm{C}$. The volumetric soil humidity had an average value of $14.2 \%$. The absolute maximum in the fluctuation of air temperature was $47.6^{\circ} \mathrm{C}$, then, of the soil temperature $19.4{ }^{\circ} \mathrm{C}$, while the least absolute fluctuation was noticeable in the volumetric soil humidity for a value of $25.4 \%$ (Table 3).

\section{Basic substrate, soil types, soil chemical properties}

Data about the geological and lithological structure was taken from the basic geological map Gospić [12], and the basic geological map Udbina [13]. The geological map of Ličko sredogorje iz characterized by layers from different age, from the Late and Middle Triassic, Jurassic, Late and Early Cretaceous, followed by Tertiary and Palaeocene, and Holocene.

In the geological-lithological as well as in the pedogenic sense the most significant rocks and basic substrates was limestone
(Cretaceous and Jurassic) as well as limestone and dolomite (Jurassic), including limestone shale, conglomerates and limestone (Tertiary), limestone dolomites and shale (Cretaceous), limestone and dolomitic limestone (Jurassic) as well as sandstone and schist.

Data about the soil was taken from the basic pedogenic maps sheet Gospić 3 [14], Novigrad 1 and Novigrad 2 [15]. The central part of the Ličko sredogorje consists of a series of soils from calcocambisol deep, calco-melanosol organic-mineral and brown variety and in a smaller amount from terra rossa deep and black soil organic-mineral and organic. On the territory of Medak, Bilaj, Ribnik, Počitelj and Plantaža there is a distric brown podsolic and typical soil, podsolic typical, and brown soil on limestone, deep. In a smaller amount, certain anthropogenic soils can also be found here. On a wider area around Gračac and Bruvno there are brown soils on limestone and dolomite, typical and podsolic, and shallow, medium deep and deep, then limestone dolomitic black soil, organic-mineral, organic and browned. The area around Ličko sredogorje also has limestone dolomitic black soil and alluvial and colluvial soil in a smaller area.

Based on the chemical analysis of the soil (Table 4) we can conclude that the studied soils have the same chemical content: the soil has a very acid reaction, it is very humus-like, it is good to richly supplied with total nitrogen, the

TABLE 4. Chemical analyses of soil in the area of Ličko polje

\begin{tabular}{|c|c|c|c|c|c|c|c|c|}
\hline \multirow[t]{2}{*}{ Subcompartment } & \multicolumn{2}{|c|}{$\mathrm{pH}$} & $\mathrm{P}_{2} \mathrm{O}_{5}$ & $\mathrm{~K}_{2} \mathrm{O}$ & \multirow{2}{*}{$\begin{array}{l}\mathbf{N} \\
\%\end{array}$} & \multirow{2}{*}{$\begin{array}{c}\text { Humus } \\
\%\end{array}$} & \multirow{2}{*}{$\begin{array}{l}\mathrm{C} \\
\%\end{array}$} & \multirow[t]{2}{*}{$\mathrm{C} / \mathrm{N}$} \\
\hline & $\mathrm{H}_{2} \mathrm{O}$ & $1 \mathrm{MKCl}$ & $\mathrm{mg} / 1$ & tla & & & & \\
\hline $39 a$ & 5.53 & 4.18 & 1.21 & 5.8 & 0.28 & 7.31 & 4.23 & 15.18 \\
\hline $51 a$ & 5.35 & 4.12 & 1.32 & 6.2 & 0.30 & 7.56 & 4.40 & 14.67 \\
\hline 63 & 5.54 & 4.13 & 0.88 & 4.4 & 0.18 & 5.20 & 3.02 & 16.78 \\
\hline
\end{tabular}


content of physiologically active phosphorus and potassium is low, and $\mathrm{C} / \mathrm{N}$ ration normal.

\section{DISCUSSION}

The Lika territory, considering the available soil types, is among one of the most optimal areas for the production of intensive cultures of fast-growing conifers. [16]. All pine cultures in Lika (classic and intensive) have been planted on Ličko and Krbavsko polje and in their surroundings. According to Vukelić [16] these areas are in the areal of the plant community of Illyrian forest of Sessile oak and hornbeam (Epimedio-Carpinetum betuli /Ht.1938/Borh. 1963) where the dominant forms are moors and bracken (Genisto-callenetum).

Apart from the air temperature which is dependant of the amount of clouds and air insolation, the amount of precipitation has the dominant effect on the growth of the vegetation because that is the main source of soil humidity. Lack of precipitation and high air temperatures weaken the resilience of forest trees because due to an increased transpiration, a large amount of water is being used [17]. The success of afforestation, that is, of establishing forest cultures, among other things, also depends on the understanding of the forest trees' habitats.

With afforestation it is necessary to consider the priority functions of the future forest cultures, and adjust accordingly the choice of tree types suitable for such climate, and consequently respect the soil characteristics. It is necessary to know the relation between what the plant requires and what the habitat can provide.

In today's conditions of climate change and the fluctuation of climate elements, it is also necessary to pay attention at the choice of afforestation species for a specific bio climate due to the survival of seedlings, as well as, due to the particular species' relation towards the climate change. The territory of Ličko sredogorje as well as the whole Lika territory has many contrast areas from the point of view of ecology and habitats which need to be considered when choosing the afforestation tree types.
Atmospheric drought is influenced by the lack of water steam. If the relative air humidity decreases significantly, transpiration increases. Terrestrial plants mostly receive water from the roots, although they sometimes also water from the atmosphere [18]. Vajda [19] says that the soil humidity factor is extremely important for the development of Common spruce. He also says that every tree type in the hotter provenance area requires a high level of humidity both in the air and the soil for its good development and growth than it would require in the colder and more humid area, and vice-versa. Therefore, he considers humidity to be the eliminating factor in many karst habitats which influences on the lack of spruce, especially if the expositions are under the influence of strong wind. According to the results of Oršanić and others [20] the soil humidity is statically conditioned with the air temperature, the dew point and the amount of precipitation in a significant way. It is well known that the relative air humidity has a big ecological significance for the supply of superficial soil layers by water condensation. Young cultures of common pine on the moor and bracken covered soils have showed their best development of the soils with the maximal quantity of the available water in the soil profile [21]. The same authors say that weather conditions in particular years have a very pronounced influence on the growing height of common pine. On the other hand, the results of Martinović and others [22] have showed that the existing differences in the growth of common pine are mostly derived from the differences in the productive value of soils.

With planning and afforestation implementation, among other factors, it is also important to respect a determined production order of the soil for specific tree types [23].

According to the results in Table 4, particularly considering the pronounced soil acidity we can conclude that the soil is more suitable for the growth and development of conifers, and for their good development, it is important to make the basic fertilization with unit phosphorus and potassium fertilizer. According to the research made by Komlenović and Rastovski [24] it is visible that the fertilization had a positive effect 
Komlenović and others [25] have showed the positive effect of fertilization on the increased concentration of biogenic elements in the needles as well as on the increased volume of this year's needles.

Looking at their characteristics, the cultures are not forest ecosystems with an established dynamic of elements circulation, and therefore, for their good development it is necessary to fertilize "for the supply" with phosphorous and potassium, because due to their features (slow shift in the soil profile) the subsequent interventions are not possible or they are poorly used. In forest plantations and in horticulture, foliar treatment of plants can be combined with the application of protective measures while with forest cultures this is difficult to implement. This fact shows the importance of doing research on the areas which are intended for the establishment of forest cultures and plantations as well as the importance of selcting a suitable species [3].

According to the research of Vukelić [16] on the Ličko polje territory, the best results were obtained with Eastern white pine, than common spruce and common pine. The poorest results were obtained with the European larch. According to Martinović [23] acid brown soils on a relic terra rossa soil under common pine and spruce have a high forest productivity value. The author further concluded that the natural productivity potential of acid brown soils on the relic terra rossa soil is used better by growing common spruce than by growing common pine. Orlić and Ocvirek [26] have concluded that common spruce deserves the best attention and has rightfully been used on our territory for the afforestation of moors and bracken covered areas.

According to the data provided by Martinović [23] black pine has the highest productivity on terra rossa soils, and lower and equal on brown soil on limestone and on rendzina on flysch. Significant differences are evident in the diameter and volume at breast height and they can be attributed to the edaphic conditions. According to Martinović
[23] with the establishment of conifer cultures in the bio climate of sessile oak and common hornbeam, bigger attention should be given to common pine than to black pine, while the priority for afforestation when looking at the soil productivity should be given to distric brown soil on relic terra rossa.

Based on the ecology demands of individual forest tree species with pioneer character $[27,28]$ and on habitat characteristics of the studied area, for the afforestation of ungrown forest land of the Ličko sredogorje territory we recommend the following forest tree species: Common birch (Betula pendula Roth.), European larch (Larix decidua Mill.), Common spruce (Picea abies Karst.), Eastern white pine (Pinus stroubus L.), Black pine (Pinus nigra subsp. austriaca Asch i Gr.), Common pine (Pinus sylvestris L.), European trembling aspen (Populus tremula L.).

\section{CONCLUSIONS}

Climate and soil are the factors that determine the habitat and which need to be taken into consideration during the selection of forest trees species for afforestation.

Average annual air temperatures on Ličko sredogorje territory have been between $8.1{ }^{\circ} \mathrm{C}$ and $9.6{ }^{\circ} \mathrm{C}$. Absolute minimal and absolute maximal air temperatures have been between $-34.6{ }^{\circ} \mathrm{C}$ and $+38.3{ }^{\circ} \mathrm{C}$. Average annual amount of precipitation were around $1500 \mathrm{~mm}$ and the percentage of precipitation in the vegetative period was between $36.4 \%$ and $50.3 \%$. Soil humidity during the whole year is sufficient. The water balance of the soil has a positive prefix all year round. When establishing the cultures, it is essential to implement agro-technical measures, namely fertilization, all accordingly to the results of chemical analysis.

For the afforestation of the un-grown forest land in the Ličko sredogorje area we recommend the following forest trees' species: Common birch (Betula pendula Roth.), Common spruce (Picea abies Karst.), 
Eastern white pine (Pinus stroubus L.), Black pine (Pinus nigra subsp. austriaca Asch i Gr.), Common pine (Pinus sylvestris L.) and European trembling aspen (Populus tremula L.).

During the selection of afforestation species it should be considered that different authors have obtained different results regarding the growth and development of specific species in the forest cultures of Lika territory, the reason for which could be traced back to the mosaic characteristic of soil, differences in the microclimate conditions and to forest cultures' management.

\section{REFERENCES}

1. MATIĆ S, DOKUŠ A, ORLIĆ S 1992 Forest Cultures and Plantations (in Croatian with English summary). In: Rauš (ed) Forest of Croatia. Forestry Faculty University of Zagreb, Croatian Forests Ltd., Zagreb, Croatia, pp 105-108

2. ČAVLOVIĆ J 2010 The First National Forest Inventory Republic of Croatia. Forestry Faculty University of Zagreb, Ministry of Regional Development, Forestry and Water Management, Zagreb, Croatia, $296 \mathrm{p}$

3. KOMLENOVIĆ N 1976 Chlorosis of conifers on dolomitic rendzina and its control (in Croatian with English summary). Sumar list 100 (10-12): 457-466

4. ŠKORIĆ A 1973 Pedological practicum (in Croatian). Faculty of Agriculture, University of Zagreb, Zagreb, Croatia, $41 \mathrm{p}$

5. ISO 103901995 Soil Quality - Determination of pH. International Organization for Standardization. Geneva, Switzerland

6. ISO 138781995 Soil Quality - Determination of total nitrogen content by dry combustion ("elemental analysis"). International Organization for Standardization. Geneva, Switzerland

7. EGNÉR H, RIEHM H, DOMINGO WR 1960 Untersuchungen über die chemische bodenanalyse als grundlage für die beurteilung des nährstoff-zustandes der böden. II. Chemísche extraktionsmethoden zur phosphor - und kaliumbestimmung. K. Lantbrttögsk, Annlr 26: 199-215

8. MONACHUS INFORMATIKA D.0.0. 2004 KlimaSoft 2.0. URL: http://www.monachus-informatika.hr

9. SPECTRUM TECHNOLOGIES SpecWare 8.0. URL: Www.specmeters.com.

10. HILL T, LEWICKI P 2007 STATISTICS: Methods and Applications. StatSoft, Tulsa, OK, USA
11. SELETKOVIĆ Z 2001 Climate and hydrological conditions in fir forests in the Dinaric region of Croatia. In: Prpić B (ed) Silver fir (Abies alba Mill.) in Croatia. Academy of Forestry Sciences, Croatian Forests Ltd, Zagreb, Croatia, pp 142-146

12. SOKAČ B, ŠĆAVNIČAR B, VELIĆ I 1976 Tumač Osnovne geološke karte SFRJ za list Gospić 1:100 000. Inst. geol. istr., Zagreb, Savezni geol. zavod, Beograd, 64

13. ŠUŠNJAR M, SOKAČ B, BAHUN S, BUKOVAC J, NIKLER L, IVANOVIĆ A 1976 Basic geological map M 1:100 000, sheet Udbina L 33-128. Inst. Geol. Istr., Zagreb, Savezni geol. zavod, Beograd.

14. MARTINOVIĆ J 1982 Tla lista Gospić 3, Zagreb, Croatia

15. MARTINOVIĆ J 1983 Tla listova Novigrad 1, 2, Zagreb, Croatia.

16. VUKELIĆ M 2001 A Review of Intensive Conifeir Cultures in Lika (in Croatian with English summary). Sumar list 125 (3-4): 185196

17. VAJDA Z 1965 Uloga klime u sušenju šuma (in Croatian). Glas šum pokuse 28: 1-12

18. GRAČANIN M, ILIJANIĆ M 1977 Introduction to plant ecology (in Croatian). Školska knjiga, Zagreb, Croatia, $318 \mathrm{p}$

19. VAJDA Z 1933 Studija o prirodnom rasprostranjenju i rastu smreke u sastojinama Gorskog kotara (in Croatian). Sumar list 57: 217-253

20. ORŠANIĆ $M$, DRVODELIĆ $D$, UGARKOVIĆ D 2011 Ecological and Biological Properties of Holm Oak (Quercus ilex L.) on the Island of Rab (in Croatian with English summary). Croat J For Eng 32 (1): 31-42 
21. MAYER B, KOMLENOVIĆ N, ORLIĆ S 1973 An investigation into the productivity of heather and bracken koils under young cultures of scots pine (Pinus sylvestris L.) In the region of the Forest Enterprise Karlovac (in Croatian with English summary). Sumar list 97 (1-2): 22-38

22. MARTINOVIĆ J, KOMLENOVIĆ N, MILKOVIĆ S 1967 Seasonal fluctuations of the content of moisture in the soil and the mineral nutrients in the needles in a young plantation of scots pine ( $P$. sylvestris L.) and eastern white pine (P. strobus L.) near the town of Ogulin (in Croatian with English summary). Sumar list 91 (3-4): 111-121

23. MARTINOVIĆ J 2003 Management of forest soils in Croatia. Croatian Forest Research Institute, Croatian Forests Ltd, Zagreb, Croatia, $525 \mathrm{p}$
24. KOMLENOVIĆ N, RASTOVSKI P 1986 Influence of Bioelements on the Growth of Three Coniferous Species (in Croatian with English summary). Sumar list 110 (1-2): 5-14

25. KOMLENOVIĆ N, MARTINOVIĆ J, MILKOVIĆ S 1969 Chlorosis of norway spruce in young cultures in the area of heather-soils (in Croatian with English summary). Sumar list 93 (3-4): 92-103

26. ORLIĆ S, OCVIREK M 1993 Growth of domestic and foreign conifer species in young cultures on fernery and health areas of Croatia (in Croatian with English summary). Rad - Šumar inst Jastrebar 28 (1-2): 91-103

27. MATIĆ S, PRPIĆ B 1983 Pošumljavanje (in Croatian). Savez inženjera i tehničara šumarstva i drvne industrije Hrvatske, Zagreb, Croatia

28. LAKUŠIĆ R 1989 Ekologija biljaka (in Bosnian). SOUR "Svjetlost" - OOUR Zavod za udžbenike i nastavna sredstva, Sarajevo, Bosnia and Herzegovina 